\title{
A Class I Jumping Clone Places the HLA-G Gene Approximately 100 Kilobases from HLA-H within the HLA-A Subregion of the Human MHC
}

\author{
Hridayabhiranjan Shukla, * Gerald A. Gillespie, † Rakesh Srivastava, $\ddagger$ \\ Francis Collins, § and Michael J. Chorney\| \\ Departments of *Human Genetics and †Internal Medicine, Yale University School of Medicine, New Haven, Connecticut 06510; \\ $¥$ Department of Immunology, Scripps Clinic and Research Foundation, La Jolla, California 92037; §Departments of Internal \\ Medicine and Human Genetics, University of Michigan, Ann Arbor, Michigan 48109; and \|Departments of Microbiology \\ and Immunology and Pediatrics, The Pennsylvania State University College of Medicine, Hershey, Pennsylvania 17033
}

Received August 3, 1990; revised February 18, 1991

By the combination of cosmid cloning, chromosomal jumping, and pulsed-field gel electrophoresis (PFGE), we have fine-mapped the $H L A-A$ subregion of the human major histocompatibility complex (MHC). Through the isolation of a class $I$ jumping clone, the $Q a$-like $H L A-G$ class I gene has been placed within $100 \mathrm{~kb}$ of $H L A-H$. The tight physical linkage of these class I genes has been further supported by hybridizing PFGE blots with locus-specific probes. It has been found that both of the above class I genes are linked to $H L A-A$, with $H L A-H$ residing no more than $200 \mathrm{~kb}$ from the $H L A-A$ gene. These data support the possible existence of a $\mathbf{Q} a$-like subregion composed of nonclassical IILA class I genes within the human MHC linked telomerically to the HLA-A locus. (c) 1991 Academic Press, Inc.

\section{INTRODUCTION}

The class I region of the human major histocompatibility complex (MHC) is composed of about $2000 \mathrm{~kb}$ of DNA (Lawrance et al., 1987) and comprises approximately 20 class I genes, pseudogenes, and gene fragments (Srivastava et al., 1985; Koller et al., 1987; Lawlor et al., 1990). The functional members of the class I gene family are among the most polymorphic genes in nature (Parham et al., 1989); the mechanisms involved in the maintenance of this diversity are largely unknown.

The construction of a molecular map of the class I region, situated on the short arm of chromosome 6 (6p21.3), is under way (Lawrance et al., 1987; Ragoussis et al., 1986, 1989; Carroll et al., 1987); this has been aided in part by the isolation of lambda and cosmid clones containing unique and low-copy-number probes that flank HLA class I sequences. These probes, in conjunction with rare-cutting restriction endonucleases (most of which are sensitive to $\mathrm{C}$ methylation) and pulsed-field gel electrophoresis (PFGE) technology, have identified the major megabase fragments upon which reside the genes encoding the transplantation antigens, HLA-A, -B, and -C. The positions of additional members of the class I gene family, such as $H L A-E$ (Srivastava et al., 1987) and cda12 (Ragoussis et al., 1989), have recently been added to the molecular map. However, the large number of highly homologous class I sequences as well as the large size of this stretch of DNA have impeded the map's completion.

Weissman (1987) has outlined alternative cloning and mapping approaches that already have proven useful in the generation of mapping data. These technologies include the use of jumping and linking libraries (Collins and Weissman, 1984; Poustka and Lehrach, 1986) as well as yeast artificial chromosome (YAC) vectors capable of cloning megabase DNA fragments (Burke et al., 1987). The former technology has proven instrumental in the successful identification of the gene responsible for cystic fibrosis (Rommens et al., 1989). Using YACs as cloning vectors, Little et al. (1989) have succeeded in isolating HLA and immunoglobulin clones. The continued application of these and other technologies will undoubtedly aid in the completion of the physical map not only of the MHC but of the human genome as well.

From deletion analysis studies (Orr and Demars, 1983 ) and data obtained in our own laboratory (M. Chorney, G. Gillespie, and S. Weissman, unpublished), it appears that many of the class I genes, pseudogenes, and gene segments are linked telomerically to the $H L A-A$ locus. In the present report, we have applied cosmid cloning, PFGE, and chromosomal jumping technologies to the mapping of several 
genes and pseudogenes within the human HLA-A class I subregion of the $\mathrm{MHC}$ and discuss the possible occurrence of a human $Q a$ region analogous to that found on chromosome 17 of the mouse (Weiss, 1987). We also discuss the possibility of a recombinational hot spot occurring in this region of the human MHC.

\section{MATERIALS AND METHODS}

\section{Cells}

3.1.0 (HLA-A2, HLA-B27, HLA-Cw1) is an EBVtransformed B-cell line that is hemizygous with respect to its MHC (Levine et al., 1985). JY is an EBVtransformed line that is serologically HLA-A2 and -B7; whether this line is an MHC homozygote as originally suggested has been questioned (van Seventer et al., 1988). Both cell lines were maintained in RPMI 1640 containing $10 \%$ fetal calf serum and $1 \%$ penicillin-streptomycin.

\section{Jumping Library Production}

The construction of the $100-\mathrm{kb}$ jumping library is described in Collins et al. (1987). Briefly, 3.1.0 DNA was partially digested with $\mathrm{MboI}$ and size-fractionated by pulsed-field gel electrophoresis. DNA in the size range of 80-130 $\mathrm{kb}$ was removed from the gel and ligated under dilute conditions in the presence of an excess of BamHI-ended supF gene. Conditions that promoted the formation of DNA circles were chosen. After ligation, the circularized genomic DNA was digested with $E c o R I$ and ligated to the lambda vector Ch3A $\Delta 1$ ac. This lambda vector, which is Aam Bam, accepts DNA in the size range of $0-12 \mathrm{~kb}$. The ligation was packaged in vitro and plated onto the supF ${ }^{-}$host strain, MC1061. Approximately $2 \times 10^{6}$ plaques were obtained. These were divided into four groups and amplified for future screening.

\subsubsection{Class I-Containing Cosmids}

The 3.1.0 cosmid libraries were made according to Lawrance et al. (1985). EcoRI and Sau3AI partially digested 3.1.0 genomic DNA was size-fractionated on a sucrose density gradient. The approximately $40-\mathrm{kb}$ genomic DNA fragments were then ligated into either EcoRI-digested pJB8 or BamHI-digested pcos2EMBL vectors. Packaged cosmids were then used to infect the recA ${ }^{-}$Escherichia coli strain HB101.

Unamplified cosmid libraries were screened using either $H L A-B 7 \mathrm{cDNA}$ (Sood et al., 1981) or the class I gene $H L A-H$ (Chorney et al., 1990) as a probe. The $H L A-H$ gene is carried on a 6.6-kb EcoRI fragment and lacks repetitive sequences. The compilation and further description of the class I-containing cosmids isolated in the Weissman laboratory at Yale University can be found in Srivastava and Lambert (1989).

\section{Locus-Specific Probes}

$H L A-G$ (6.0)-specific probe. On the basis of nucleotide sequencing (Srivastava and Lambert, 1989), one of the $E c o R I$ class I ${ }^{+}$fragments contained within CosRS27 was found to contain an allele of the $H L A$ 6.0 gene described previously by Geraghty et al. (1987). This gene has been subsequently redesignated $H L A-G$ (Koller et al., 1989). A 700-bp low-copy EcoRI fragment located approximately $17 \mathrm{~kb}$ upstream of the $H L A-G$ gene was subcloned into pUC19 and termed pMC27.7 (see Fig. 3). The probe resides within a nonpolymorphic 2 -kb HindIII fragment but weakly cross-hybridizes to a series of four polymorphic HindIII fragments, each of which is linked to a specific HLA-A gene (Chorney et al., 1991). The locus defined by this probe has been designated D6S110 (Chorney et al., 1991).

HLA-H-specific probe. A 700-bp EcoRI fragment located approximately $21 \mathrm{~kb} 5^{\prime}$ of the $H L A-H$ gene was subcloned into pUC19 (subsequently termed pMC6.7; Chorney et al., 1990). This fragment was derived from CosRS6, the map of which is presented in Fig. 3. On Southern genomic blots, pMC6.7 hybridized most strongly to a nonpolymorphic HindIII fragment of 10 $\mathrm{kb}$ but cross-reacted with several bands, two of which displayed polymorphism. Among the clones in our class $\mathrm{I}^{+}$collection, the probe hybridized only to CosRS6. The specificity of this fragment in hybridizing only to CosRS6 was previously noted (Srivastava et al., 1986).

$H L A-A$-specific probe. A 490-bp PvuII-MspI fragment derived from the $3^{\prime}$ untranslated region of the $H L A-A 2$ gene was subcloned into pUC9 by Koller $e t$ al. (1984) and termed pHI,A-2A.1. The probe hybridized most strongly to fragments carrying $H L A-A$ genes but was also observed in our experiments to cross-hybridize weakly to fragments carrying an $H L A-A$-linked pseudogene (Chorney et al., 1990) and HLA-H.

\section{Pulsed-Field Gel Electrophoresis}

3.1.0 genomic DNA, digested in agarose plugs, was resolved on OFAGE (orthogonal field alteration gel electrophoresis) gels using an LKB Pulsaphor gel apparatus. Gels contained 1\% agarose, $0.5 \times$ TBE (1X TBE equals $0.089 M$ Tris borate, $0.089 M$ boric acid, $0.002 M$ EDTA, $\mathrm{pH} 8.0$ ) and were run at $14^{\circ} \mathrm{C}$ for $48 \mathrm{~h}$ at $250 \mathrm{~V}$ with a pulse time of $2 \mathrm{~min}$. After electrophoresis, the gels were depurinated with $0.2 \mathrm{~N} \mathrm{HCl}$ for 15 min and then denatured with $0.5 \mathrm{~N} \mathrm{NaOH}$. The gels were then blotted against $0.5 \mathrm{~N} \mathrm{NaOH}$ and $1.5 \mathrm{M}$ 


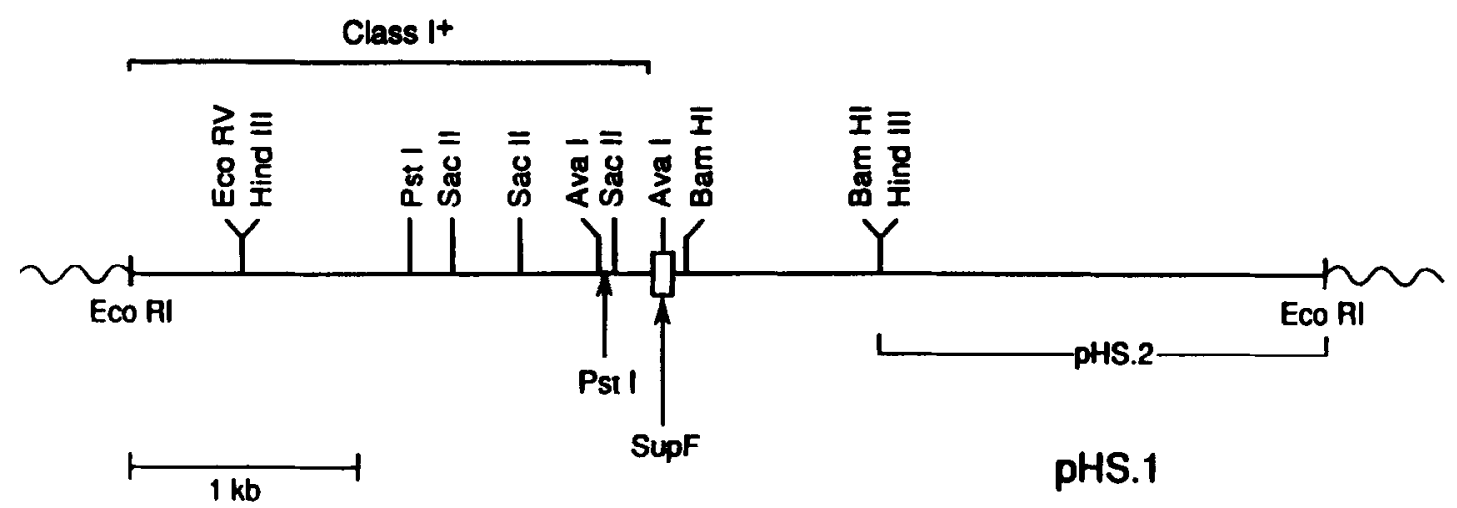

FIG. 1. Restriction map of the class I jumping clone pHS.1. The original jumping clone insert was removed from bacteriophage $\lambda$ (Ch3A $\Delta 1 \mathrm{ac}$ ) by digesting with $E$ coRI and subcloned into the plasmid vector pUC19. Class $\mathrm{I}^{+}$designates the region that was derived from the class I gene $H L A-H$. The box marked SupF represents the suppressor tRNA gene which contains a convenient AvaI site. pHS.2 marks the unique-copy $E$ coRI to BamHI jump fragment, which was subsequently subcloned into Bluescript (KS) ${ }^{-}$and used on pulsed-field gels to identify the jump region. Restriction sites are indicated; a 1-kb scale bar is presented below, left

$\mathrm{NaCl}$ onto Hybond nylon filters (Amersham), vacuum-dried, and uv-irradiated using 254-nm shortwave uv for 2 min before the commencement of prehybridization. Restriction enzyme-digested JY genomic DNA embedded in plugs was resolved by using a Bio-Rad CHEF gel system. Pulse times were $60 \mathrm{~s}$ for $15 \mathrm{~h}$ followed by $90 \mathrm{~s}$ for $9 \mathrm{~h}$. Hybridization conditions for the blotted OFAGE and CHEF gels were according to Church and Gilbert (1984). Final washings after the completion of hybridization were performed with $0.2 \times \mathrm{SSC}(1 \times \mathrm{SSC}$ equals $0.15 \mathrm{M} \mathrm{NaCl}$ and 0.015 $M$ sodium citrate) at $65^{\circ} \mathrm{C}$.

\section{Nucleic Acid Blotting and Hybridization}

DNA blotting was performed according to the method of Southern (1975). Except for blotted OFAGE and CHEF gels, blots were prehybridized and hybridized using nonfat dry milk as described by Johnson et al. (1984). DNA was labeled with $\left[{ }^{32} \mathrm{P}\right] \mathrm{dCTP}$ by the random priming method of Feinberg and Vogelstein (1983).

\section{RESULTS}

\section{Isolation of the Class I Jumping Clone pHS.1}

An amplified jumping library from the MHC hemizygous B-lymphoblastoid cell line 3.1.0 (HLA-A2, B27, Cw1) was screened with a labeled 6.6-kb EcoRI fragment carrying the $H L A-H$ class I gene (Chorney et al., 1990) as a probe. A total of 300,000 plaques were screened; 6 clones were initially isolated from the library and one was chosen for further analysis. The insert from this class $\mathrm{I}^{+}$clone, which was contained within a 5-kb EcoRI fragment, was subsequently subcloned into the plasmid pUC19 to facilitate sequencing and mapping and was termed pHS.1 (Fig. 1).

\section{pHS.1 Contains a Portion of the HLA-H Class I Gene}

To aid us in characterizing our jumping clones, we first subcloned the majority of the EcoRI fragments carrying class I genes into the Bluescript (KS) ${ }^{-}$plasmid (Stratagene, La Jolla, CA); these fragments were derived from both phage and cosmid clones isolated from 3.1.0 genomic libraries. Subcloning was followed by end sequencing using both forward (universal) and reverse M13 oligonucleotide primers; this allowed the creation of a database of EcoRI end sequences.

To characterize pHS.1 initially, we used both the forward and the reverse M13 oligonucleotide primers to obtain the nucleotide sequence from the ends of the insert. Sequence from the forward primer (which was coincidentally adjacent to the class I-hybridizing sequence) demonstrated that the jumping clone possessed $100 \%$ nucleotide homology to the comparable end sequence of the EcoRI fragment carrying the $H L A-H$ gene [the $E c o$ RI restriction site is located approximately $1200 \mathrm{bp}$ upstream of the translation initiation codon (Chorney et al., 1990)]. Included in the comparison was over 300 nucleotides read from the jumping clone sequencing gel. Both pHS.1 and the EcoRI fragment containing $H L A-H$ possessed approximately $98 \%$ homology compared to the comparable region from the EcoRI fragment carrying the $H L A-A 2$ gene. Compared to the EcoRI fragment carrying the $H L A-B 27$ gene, the jumping clone possessed only $90 \%$ homology over the comparable 300-bp stretch (data not shown).

The restriction map of pHS.1 is presented in Fig. 1. The supF gene, characterized by an AvaI site, lies approximately in the middle of the insert. The class Ihybridizing fragment (approximately $2.0 \mathrm{~kb}$ of sequence) is shown to the left of the supF gene. The restriction map of the class I fragment contained in 
pHS.1 was identical to the restriction map of $H L A-H$ with respect to all of the enzymes tested. Sites unique to $H L A-H$, such as EcoRV (position 346) and PstI (position 1284), were also found within the class I-hybridizing fragment of pHS.1 at approximately identical positions with respect to the EcoRI end. For these reasons, we feel that the class I fragment contained within pHS. 1 is derived from the $H L A-H$ gene.

Nucleotide sequence derived from the reverse primer and coming from the jump fragment failed to match any of the sequences then available in GenBank.

\section{pHS.1 Jumps into a Group of Overlapping Cosmids, One of Which Contains the HLA-G Class I Gene}

The 1.8-kb EcoRI-BamHI fragment from pHS.1 (derived from the non-class I-hybridizing jump fragment) was isolated and subcloned into pBluescript (KS) ${ }^{-}$. This subclone was termed pHS.2. We used pHS.2 as a probe and hybridized it to our cosmid clones containing class I genes. After high stringency washing, we observed that it hybridized to CosRS27, which contains the $H L A-G$ class I gene, as well as to a group of near identical cosmids, all of which contain a putative class I pseudogene (CosRS23, RS29, RS34, and RS40) (Fig. 2A). Digestion of cosmid CosRS23, representative of the group, as well as CosRS27 with EcoRI followed by Southern blotting and hybridization with pHS.2 demonstrated that a 3.0-kb EcoRI fragment was recognized in each clone (Figs. $2 \mathrm{~B}$ and C). EcoRI digestion of genomic DNA from unrelated individuals followed by hybridization with pHS.2 yielded a 3-kb fragment (data not shown). Since pHS.2 failed to cross-react with any other genomic fragments, it appears that the probe is unique copy.

We additionally confirmed that the 3.0-kb EcoRI fragment was the fragment to which our clone jumped (the starting point being the $H L A-H$ class I gene). First, EcoRI-BamHI double digests of both CosRS27 and CosRS40 DNA followed by hybridization with pHS.2 yielded a 1.8-kb hybridizing fragment. Second, after subcloning into the pBluescript $(\mathrm{KS})^{-}$plasmid, the 3.0-kb EcoRI fragment from CosRS27 was end sequenced. The sequence of one end was identical to the class $\mathrm{I}^{-} E c o$ RI end of pHS.1 ( $300 \mathrm{bp}$ read off of the sequencing gel).

The EcoRI restriction maps of CosRS27 and a representative of the overlapping group of cosmids (CosRS40) are presented in Fig. 3; also shown is the map of CosRS6 which contains the class I gene $H L A$ $H$. As the hybridization data using pHS.2 suggested above, CosRS27 and the CosRS23, RS29, RS34, and
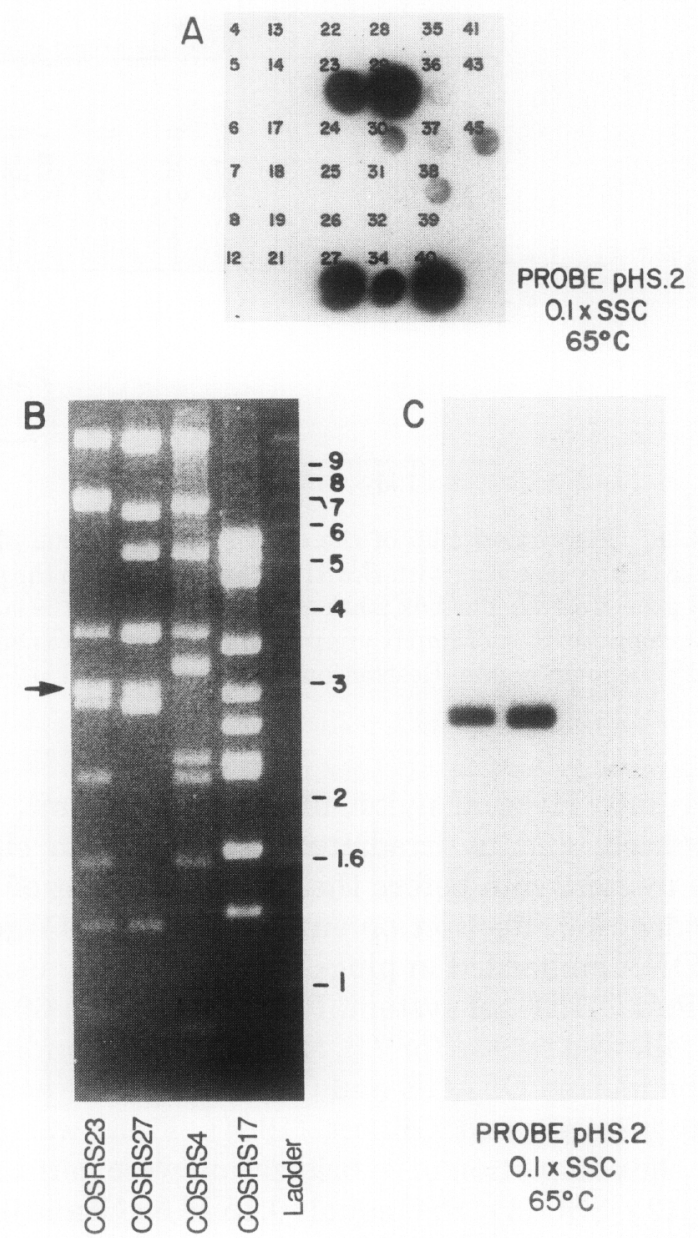

C

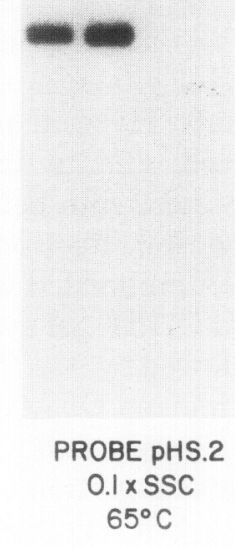

FIG. 2. Hybridization of pHS.2 to class I gene-containing cosmids. (A) Approximately $0.01 \mu \mathrm{g}$ of DNA from individual class I-containing cosmid clones was spotted onto Biotrans (ICN, Costa Mesa, CA) nylon filter and probed with pHS.2. The filter was washed extensively with $0.1 \times \mathrm{SSC}$ at $65^{\circ} \mathrm{C}$. Positive clones are CosRS23, CosRS27, CosRS29, CosRS34, and CosRS40. A very low level of background is visible with Cos30, CosRS37, CosRS38, and CosRS45. (B) DNA from two of the positive clones (CosRS23 and CosRS27) as well as DNA from two of the negative clones (CosRS4 and CosRS17, chosen at random) was digested with EcoRI, electrophoresed on a $1 \%$ agarose gel, and stained with ethidium bromide. The positions of molecular size markers (1-kb ladder from BRL, Gaithersburg, MD) are to the right of the stained gel. (C) The same gel as in $\mathbf{B}$, blotted onto nylon membrane and probed with pHS.2. The arrow to the left of $B$ shows the common $3.0-\mathrm{kb}$ fragment in both CosRS23 and CosRS27 to which pHS.2 hybridized.

RS40 group of cosmids were found upon further inspection to overlap (Fig. 3).

The need for proceeding with caution in assigning jumps in the class I region is due to the fact that the HLA class I family is composed of recently duplicated genes (and their attached flanking sequences), all of which possess high levels of nucleotide homology (Chorney et al., 1990). We feel that these data in toto 


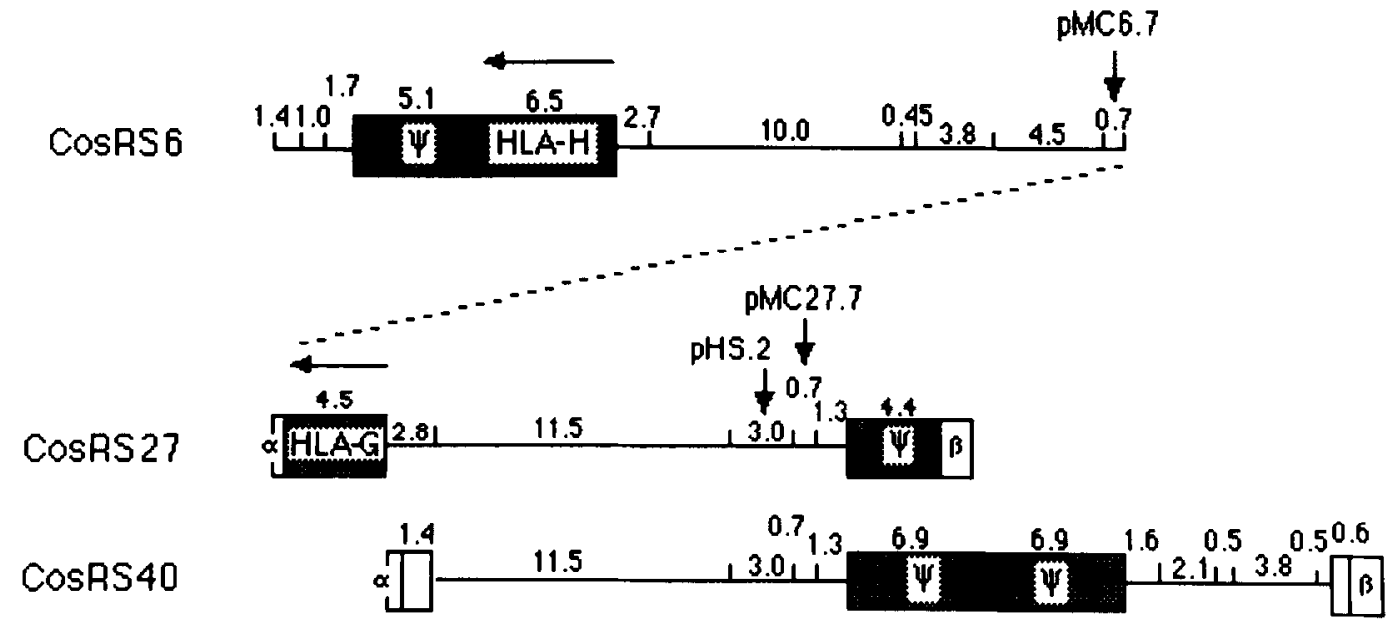

FIG. 3. EcoRI restriction maps of cosmids CosRS6 (vector pJB8), CosRS27 (vector pcos2EMBL), and CosRS40 (pcos2EMBL). To obtain restriction maps, cosmid DNA was linearized with ClaI or XhoI (CosRS27 and CosRS40) or with SalI (CosRS6), all of which cleave within the vector sequences. This was followed by partial digestion with $E c o$ RI. The partial digests were run overnight on 1.5 -mm vertical field inversion agarose gels as described in Chorney et al. (3). After blotting, the gels were probed with appropriate vector fragments located on either side of the ClaI, Xhol, and Sall restriction sites. High-molecular-weight markers from BRL (Gaithersburg, MD) served as size standards. $\alpha$ and $\beta$ refer to pcos2EMBL vector fragments that fused with insert DNA (Sau3AI ends ligated into the BamHI cloning site) during the production of the cosmid library. EcoRI fragments carrying class I gene sequences are presented as shaded boxes. The symbol $\psi$ refers to a confirmed pseudogene in CosRS6 and a putative class I pseudogene contained in cosmids CosRS27 and CosRS40. The positions of probes pMC6.7, pMC27.7, and pHS.2 are also marked. The dashed line indicates the linkage of the cosmids as defined by jump clone pHS.1 and represents approximately $40 \mathrm{~kb}$ (or less) of as yet uncloned genomic DNA. The process of orienting CosRS6 with respect to the overlapping cosmids CosRS27 and CosRS40 as well as orientating the direction of $H L A-H$ and $H L A-G$ transcription is described under Results.

confirm that pHS.1 jumped from $H L A-H$ into the $H L A-G$ locus. More importantly, these data place $H L A-G$ in close physical proximity (approximately $100 \mathrm{~kb})$ to the $H L A-H$ gene.

\section{Orientation of the Jump}

The orientation of the jump as well as the transcriptional orientation of both the $H L A-H$ and the $H L A-G$ class I genes was determined by the following experiments. First, the orientation of the jump was accomplished by digesting CosRS27 with BamHI followed by probing consecutively with pMC27.7 and pHS.2. The strategy was as follows: Since pHS.2 (composed of a 1.8-kb EcoRI-BamHI fragment) falls within the 3.0-kb EcoRI fragment that lies next to pMC27.7, hybridization of both fragments to the identical $\mathrm{BamHI}$ fragment would indicate that pHS.2 lies immediately adjacent to pMC27.7 (the 700-bp EcoRI fragment comprising pMC27.7 does not contain a $B a m H I$ site). Hybridization of fragments to different DNA bands would indicate that pHS.2 was at the opposite end of the 3.0-kb EcoRI fragment. Indeed, the probes hybridized to different DNA segments (data not shown). Therefore, this result places $H L A-H$ to the left of $H L A-G$ as presented schematically in Fig. 3. The transcriptional orientation of $H L A-G$ was determined by subcloning the EcoRI fragment containing the $H L A-G$ gene from CosRS27 followed by end sequencing. One end of the fragment contained plasmid due to a fusion with vector during cosmid construction; the other end was found to contain the $5^{\prime}$ end of the class I HLA-G gene. On the basis of the orientation of the jump and the sequencing results, both $H L A-G$ and $H L A-H$ possess the same transcriptional orientation.

We believe that the class $\mathrm{I}^{+} E c o R I$ fragments $5^{\prime}$ to $H L A-G$ (Fig. 3) carry a single class I pseudogene allelic to the $H L A-X$ (HLA-7.5p, HLA-9p) class I gene isolated from the B-LCL 721 line as described by Koller et al. (1987, 1989). These investigators also demonstrated by cosmid cloning that their $H L A-G$ and $H L A-X(7.5 p, 9 p)$ cosmid clones overlapped. Using an exon 2 oligonucleotide probe derived from an HLA class I consensus sequence, we have observed the hybridization of the probe to CosRS40 but not to CosRS27 (M. Chorney, unpublished). Given the results above and assuming that the EcoRI fragments carry a single class I pseudogene, the transcriptional orientation of the $H L A-X$ pseudogene would be identical to $H L A-G$ and $H L A-H$. Therefore, the three genes would be aligned head to tail. The approximate map positions of the genes within the class I region of the MHC are presented in Fig. 6; their orientation along the short arm of chromosome 6 is further discussed below. 


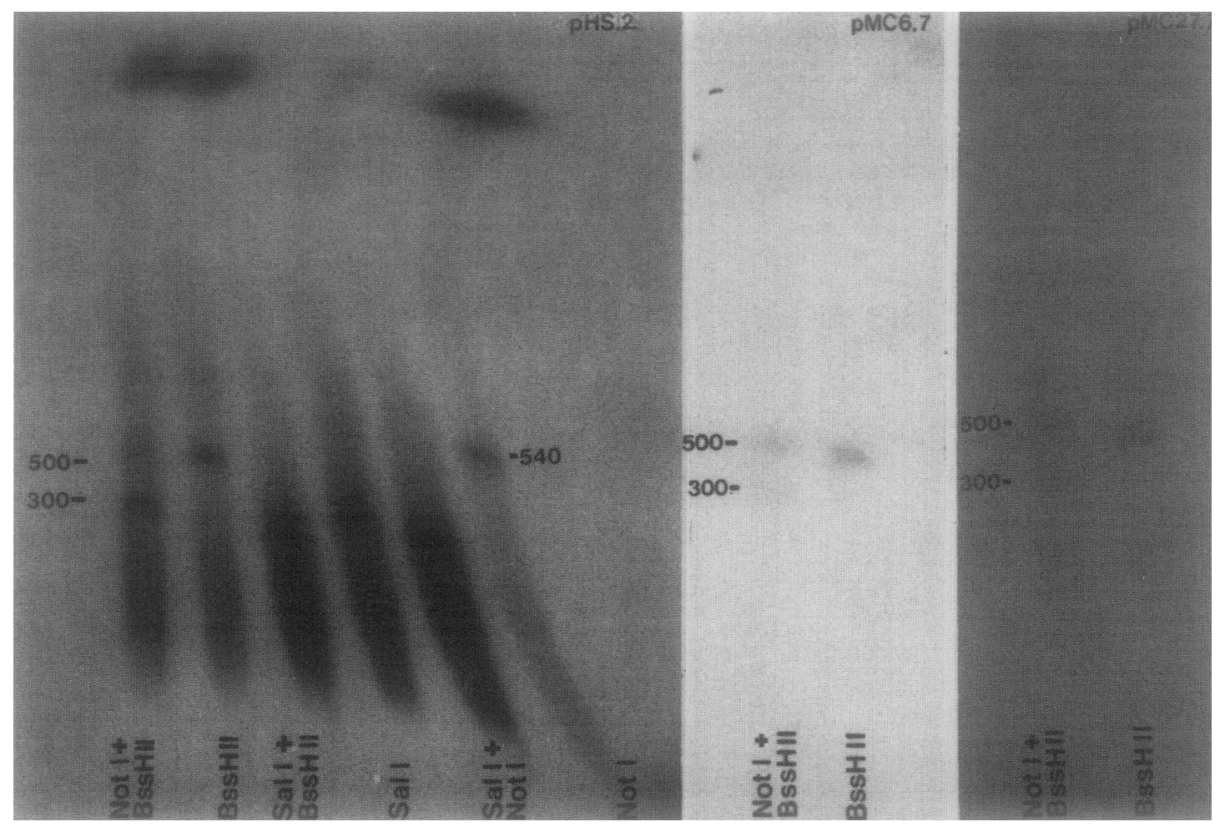

FIG. 4. OFAGE blots of 3.1.0 DNA probed with $H L A-G$ (pHS.2; pMC27.7) and $H L A-H$ (pMC6.7) locus-specific probes. Yeast chromosomes and bacteriophage $\lambda$ multimers served as size standards. Molecular sizes are indicated to the left of the figure. Enzymes used for digestion are presented below each lane. The enzymatic treatment of 3.1.0 genomic DNA with BssHII and NotI consistently resulted in the incomplete cleavage of the 500 - and $540-\mathrm{kb}$ fragments, presumably due to partial methylation.

pHS.2 and Low-Copy Probes from the HLA-H and

HLA-G Loci Hybridize to the Same Megabase

Restriction Fragments

We next hybridized pHS.2 to blots of 3.1 .0 genomic DNA digests that had been separated by OFAGE. pHS.2 hybridized to $540-\mathrm{kb}$ NotI and $500-\mathrm{kb}$ Bss HII fragments (Fig. 4). BssHII-NotI double digestion yielded a fragment of approximately $300 \mathrm{~kb}$. pHS.2 also hybridized to a 300-kb Sall fragment that is contained within both the NotI and the BssHII fragments. Identical results were obtained by using the $H L A-G$-specific 700-bp EcoRI fragment (pMC27.7) that lies next to the $3.0-\mathrm{kb} E c o$ RI fragment within CosRS27 (Fig. 4; only the BssHII and BssHII-NotI digestions are shown). Like pHS.2 and pMC27.7, both the $H L A-H$ locus-specific probe pMC6.7 (Fig. 4) and the $H L A-A$-specific probe pHLA-2a.1 also hybridized to the same fragments (see Chorney et al., 1990). These data demonstrate that the jump is totally contained within at most $300 \mathrm{~kb}$ of 3.1.0 DNA as defined by SalI single and BssHII-NotI double digests.

We next hybridized the same probes to PFGE blots of JY DNA. This was done because the 3.1.0 cell line had originally been gamma-irradiated; the possibility existed, therefore, that the single copy of the 3.1.0 MHC had undergone rearrangement. Figure 5 shows the results of the Southern blottings. First, pHLA2a.1, pMC6.7, pHS.2, and pMC27.7 (data not shown) all hybridized to an identical NotI megabase fragment of 500-600 kb as was observed for 3.1.0. However, digestion with $B s s \mathrm{HII}$ alone yielded a series of three radioactive fragments, the largest of which was $300 \mathrm{~kb}$ and identical for each probed used. The most plausible explanation for the multiple BssHII fragments is partial methylation of the BssHII recognition sites (GCGCGC); these data suggest that the JY genomic DNA in this class I subregion is undermethylated compared to 3.1.0. The second of the BssHII fragments (approximately $250 \mathrm{~kb}$ ) recognized by each of the probes (pMC27.7 data not shown) was also identical. BssHII followed by NotI digestion failed to reduce any of the BssHII fragments' molecular sizes, suggesting that the BssHII fragments are totally contained within the NotI megabase fragment. These data further suggest that the three genes are tightly linked in the JY genome and fall within a common $250-\mathrm{kb} B s s \mathrm{HII}$ fragment. BssHII and NotI in combination with additional restriction enzymes are being used to determine the exact distances separating the three genes. In addition, it would appear that the 3.1.0 genome has not undergone major rearrangements in this class I subregion as assessed by PFGE.

\section{DISCUSSION}

In the present report, we have demonstrated the physical linkage of two class I genes found within the 540 -kb NotI genomic fragment that partially constitutes the class I region of the human MHC. Our map- 


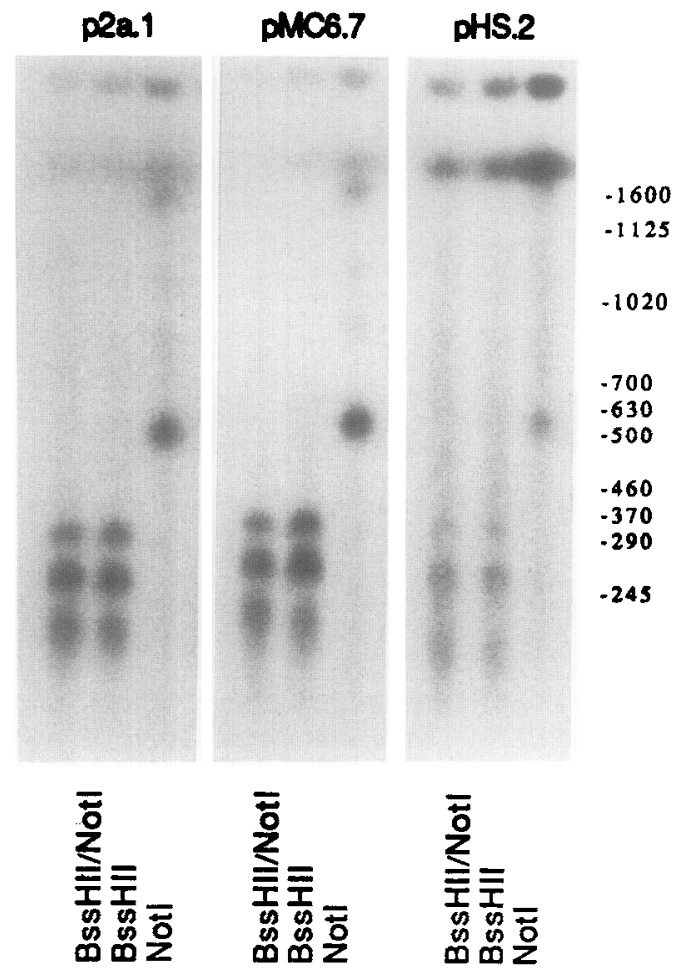

FIG. 5. CHEF gel blots of JY DNA probed with pHLA-2a.1 (p2a.1), pMC6.7, and pHS.2. The multiple digests presented in the figure were run side-by-side on a single gel and blotted. Afterward, the nylon membrane was cut into strips and probed. To determine whether the fragments hybridized by each probe were identical, individual blots were stripped and rehybridized with a different probe. Enzyme digests are presented below; molecular sizes are to the right.

ping assignments have been aided by the isolation and characterization of a class I jumping clone (pHS.1) that has allowed us to place the $H L A-G$ class I gene (originally termed $H L A-6.0$; Geraghty et al., 1987) within approximately $100 \mathrm{~kb}$ of $H L A-H$ (Chorney et $a l ., 1990)$. However, the exact distance separating the two nonclassical class I genes may be less, due to the fact that the range of jumps performed with clones isolated from the same library extends from as little as 30 to $130 \mathrm{~kb}$ (average of 60-65 kb; F. Collins, personal observation). The close linkage of both genes to the $H L A-A$ locus has been further supported by PFGE experiments. Using low-copy probes from clones containing $H L A-H, H L A-G$, and $H L A-A$ genes (this report and Chorney et al., 1990) as well as a unique-copy probe from the pHS.1 jumping clone, we have observed their hybridization to identical $300-\mathrm{kb}$ $B s s \mathrm{HII}-\mathrm{NotI}$ and 250-kb BssHII genomic fragments from the B-lymphoblastoid lines 3.1.0 and JY, respectively.

Although the three class I genes are linked within a 250- to $300-\mathrm{kb}$ stretch of DNA, it is important to address the question of whether $H L A-H$ is positioned centromeric or telomeric to $H L A-A$. At present, the possibility that $H L A-H$ lies centromeric to $H L A-A$ and that the clone pHS.1 has jumped over the $H L A$ A2 gene cannot be conclusively ruled out. We feel, however, that the jump extends telomeric and away from the $H L A-A$ gene, with the $H L A-H$ gene positioned between $H L A-A$ and $H L A-G$. In support of this hypothesis is the fact that we have cloned $56.9 \mathrm{~kb}$ of DNA located between $H L A-H$ and the jump fragment. A portion of this DNA is contained within cosmid RS42, which partially overlaps CosRS6 (Chorney et al., 1990). Since the jump library is approximately $100 \mathrm{~kb}(60-65 \mathrm{~kb}$ average), slightly greater than $40 \mathrm{~kb}$ of DNA has yet to be cloned. Our $H L A-A 2$ cosmid, CosRS28, consists of $40 \mathrm{~kb}$ of DNA; we have been unable to show any overlap with either CosRS42 or CosRS27. If $H L A-A 2$ were positioned between $H L A$ $H$ and $H L A-G$, it would require that the $40 \mathrm{~kb}$ of CosRS28 be contained exclusively within the approximately $40 \mathrm{~kb}$ stretch of uncloned DNA. This appears unlikely. Although the exact distance separating $H L A-H$ from $H L A-A 2$ has not yet been established, the distance can be no greater than $200 \mathrm{~kb}$ given the PFGE data presented above. The map of the HLA-A subregion is presented in Fig. 6.

Class I $Q a$ genes in the mouse are of limited polymorphism and expressed only in certain tissues, unlike their classical counterparts found within the $\mathrm{H}-2$ region. The mouse $Q a$ region falls immediately telomeric of the $H-2 D$ region and contains 8 to 10 class I-hybridizing genes and pseudogenes located within approximately $200 \mathrm{~kb}$ of DNA (Flavell et al., 1986). On the basis of the findings of this report, we have localized two novel class I genes and their two linked pseudogenes (Fig. 6) telomeric to HLA-A2 and have established a possible $Q a$-like subregion within the human MHC broadly analogous to that of the mouse; however, unlike the mouse $Q a$ region, the human $Q a$ region may be more sparsely populated with class I genes. One of the genes, HLA-G, is expressed (Rinke de Wit et al., 1990; Ellis et al., 1990; Kovats et al., 1990; Shukla et al., 1990) and due to a termination in its sixth exon resembles a mouse $Q a$ gene (Geraghty et al., 1987). The other gene, which has been designated $H L A-H$ by the WHO Nomenclature Committee, is most probably a pseudogene due to an in-frame termination codon in its fourth exon; however, at the RNA level, this gene is also expressed (Chorney et al., 1990; Zemmour et al., 1990). Two additional members of this assemblage include the $H L A-F$ class I gene (Koller et al., 1989) and cda12 (Ragoussis et al., 1989). $H L A-F$ possesses a unique pattern of tissue expression (Geraghty et al., 1990); it has been physically linked to the $H L A-G$ gene and maps telomeric to $H L A-G$ on chromosome 6 (D. Geraghty, personal communication). The cda12 gene has been mapped to 


\section{Chromosome 6 -Class I Region of the MHC}

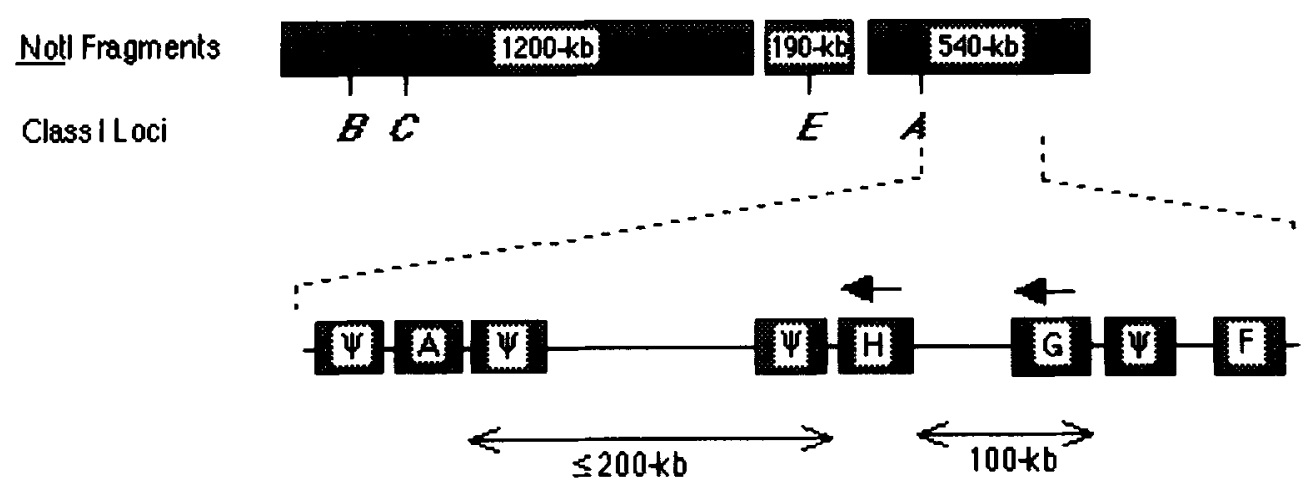

FIG. 6. Map of the human $H L A-A$ class I subregion. The NotI fragments partially composing the class I region are presented above along with the positions of the major class I loci. The approximate positions of the HLA-A,HLA-H,HLA-G, and HLA-F genes (from Ref. (19)) along with their linked pseudogenes $(\psi)$ are indicated on an enlargement of a section of the 540-kb NotI fragment. The exact physical distance separaling $H L A-A$ from $H L A-H$ is unknown (represented by the arrow) but can be no greater than 200 kb. The transcriptional orientation of the $H L A-A$ gene and its two linked pseudogenes with respect to $H L A-H$ and $H L A-G$ on the short arm of chromosome 6 has not yet been determined. The centromere is proximal to $H L A-B$ in the figure.

within $50 \mathrm{~kb}$ of $H L A-A$ (Ragoussis et al., 1989). Its exact orientation with respect to the nonclassical class I genes studied in this report has not been determined.

The nonclassical human class I genes residing within the 540-kb NotI fragment have presumably arisen by the process of gene duplication prior to the separation of the chimpanzee from man; this is supported by the fact that $H L A-A 2$ flanking probes hybridize to fragments flanking the $H L A-H$ and $H L A-G$ class I genes (Chorney et al., 1990). The argument of a recent duplication is further supported by the $H L A-H$ gene, which is greater than $90 \%$ homologous in its overall nucleotide sequence to certain $H L A-A$ class I genes (Chorney et al., 1990; Zemmour et al., 1990). The duplication phenomenon is reminiscent of that in the mouse, where $H-2 K$ and certain $Q a$ genes most probably have arisen through the duplication of an ancestral class I gene (Weiss, 1987). At present, the evolutionary relationships between the mouse $Q a$ and Tla genes and the human nonclassical MHC class I genes are unclear (Stroynowski, 1990).

Koller et al. (1989) have studied the segregation of locus-specific markers in recombinant MHC families. Their genetic data have demonstrated that the $H L A$ $G$ locus lies $8 \mathrm{cM}$ telomeric to the $H L A-A$ subregion; this subregion, on the basis of study of HLA loss mutants, is composed in part of both the $H L A-A$ and the $H L A-5.4 p$ (an allele of $H L A-H$ ) class I genes, which appear to be in tight physical linkage. A surprising result of this present study is the suggestion of a possible recombinational hot spot within certain human MHC haplotypes. This is based on the PFGE results which have demonstrated that the physical distance separating the $H L A-A$ and $H L A-G$ loci in the 3.1 .0 cell line is no greater than $300 \mathrm{~kb}$ (approximately $100 \mathrm{~kb}$ minimum) compared to the nearly $8 \mathrm{cM}$ of genetic distance separating the same class I genes in certain individuals (Koller et al., 1989). If one divides the genetic distance $(8 \mathrm{cM})$ converted into kilobases $(1 \mathrm{cM}$ is roughly equivalent to $1 \mathrm{Mb}$; Ott, 1985) by the actual physical distance (100-300 kb), one obtains a factor of 27-80. This suggests that because of increased recombination in the area of those MHC haplotypes studied, the genetic distance may be 27-80 times greater than that predicted by the physical distance alone. It may be noted that discrepancies in genetic versus physical distances have been previously noted (Fulton et al., 1989; Higgins et al., 1990) as have MHC recombinational hot spots at least in the mouse (Steinmetz et al., 1986; Kobori et al., 1986). Although these results are only suggestive, the confirmation that a bona fide recombinational hot spot exists within the human $Q a$-like region of the human MHC clearly warrants further investigation.

\section{ACKNOWLEDGMENTS}

The authors thank Dr. Sherman Weissman for his generous support and helpful discussions during the performance of this research. This work was supported in part by a grant from the Children's Miracle Network Telethon Fund (M.J.C.) and NIH Grants CA47519 and AI26334-01A2 (R.S.).

\section{REFERENCES}

1. Burke, D. T., Carle, G. F., AND Olson, M. V. (1987). Cloning of large segments of exogenous DNA into yeast by means of artificial chromosome vectors. Science 236: 806-812.

2. Carroll, M. C., Katzman, P., Ai.icot, E. M., Kot.t.er, B. H., Geraghty, D. E., ORR, H. T., Strominger, J., AND 
SPIES, T. (1987). Linkage map of the human major histocompatibility complex including the tumor necrosis factor gene. Proc. Natl. Acad. Sci. USA 84: 8535-8539.

3. Chorney, M. J., Sawada, I., Gillespie, G. A., SRIvastava, R., PAN, J., AND WeISSMaN, S. M. (1990). Transcription analysis, physical mapping, and molecular characterization of a nonclassical human leukocyte antigen class I gene. Mol. Cell. Biol. 10: 243-253.

4. Chorney, M. J., Le Gall, J.-Y., and Drysdale, J. W. (1991). D6S11U detects polymorphic HindIII fragments associated with individual HLA-A class I haplotypes. Nucleic Acids Res. 19: 200.

4a. Church, G. M., and Gilbert, W. (1984). Genomic sequencing. Proc. Natl. Acad. Sci. USA 81: 1991-1995.

5. Collins, F. S., AND Weissman, S. M. (1984). Directional cloning of DNA fragments at a large distance from an initial probe: A circularization method. Proc. Natl. Acad. Sci. USA 81: $6812-6816$.

6. Collins, F. S., Drumm, M. L., Cole, J. L., Lockwood, W. K., VANDE Woude, G. F., AND IANNUZzi, M. C. (1987). Construction of a general human chromosome jumping library, with application to cystic fibrosis. Science 235: 10461049.

7. Dunham, I., Sargent, C. A., Trowsdale, J., and CampBELL, R. D. (1987). Molecular mapping of the human major histocompatibility complex by pulsed-field gel electrophoresis. Proc. Natl. Acad. Sci. USA 84: 7237-7241.

8. Ellis, S. A., Palmer, M. S., AND McMichael, A. J. (1990). Human trophoblast and the choriocarcinoma cell line BeWo express a truncated HLA class I molecule. J. Immunol. 144: $731-735$

9. Feinberg, A. P., AND Vogelstein, B. (1983). A technique for radiolabeling DNA restriction endonuclease fragments to high specific activity. Anal. Biochem. 132: 6-13.

10. Flavell, R. A., Allen, H., Burkly, L. C., Sherman, D. H., WANECK, G. L., AND WIDERA, G. (1986). Molecular biology of the H-2 histocompatibility complex. Science 233: 437-443.

11. Fulton, T. R., Bowcock, A. M., Smith, D. R., Daneshvar, L., Green, P., Cavalli-Sforza, L. L., AND Donis-Keller, H. (1989). A 12 megabase restriction map at the cystic fibrosis locus. Nucleic Acids Res. 17: 271-284.

12. Geraghty, D. E., Koller, B. H., AND ORR, H. T. (1987). A human major histocompatibility complex class I gene that encodes a protein with a shortened cytoplasmic segment. Proc. Natl. Acad. Sci. USA 84: 9145-9149.

13. Geraghty, D. E., Wei, X., ORR, H. T., AND Koller, B. H. (1990). Human leukocyte antigen F (HLA-F): An expressed HLA gene composed of a class I coding sequence linked to a novel transcribed repetitive element. J. Exp. Med. 171: 1-18.

14. Higgins, M. J., Turmel, C., Noolandi, J., Neuman, P. E., AND LALANDE, M. (1990). Construction of the physical map for three loci in chromosome band 13q14: Comparison to the genetic map. Proc. Natl. Acad. Sci. USA 87: 3415-3419.

15. Johnson, D. A., GauTsCh, J. W., Sportsman, J. R., AND ELDER, J. H. (1984). Improved technique utilizing nonfat dry milk for analysis of proteins and nucleic acids transferred to nitrocellulose. Gene Anal. Tech. 1: 3-8.

16. Kobori, J. A., Strauss, E., Minard, K., and Hood, L. (1986). Molecular analysis of the hotspot of recombination in the murine major histocompatibility complex. Science 234: 173-179.

17. Koller, B. H., Sidwell, B., DeMars, R., ANd OrR, H. T. (1984). Isolation of HLA locus-specific DNA probes from the 3'-untranslated region. Proc. Natl. Acad. Sci. USA 81: 51755178.

18. Koller, B. H., Geraghty, D., ORR, H. T., ShImizu, Y., AND DEMARs, R. (1987). Organization of the human class I major histocompatibility complex genes. Immunol. Res. 6: 1-10.

19. Koller, B. H., Geraghty, D. E., DeMars, R., Duvick, L., RICH, S. S., AND ORR, H. T. (1989). Chromosomal organization of the human major histocompatibility complex class I gene family. J. Exp. Med. 169: 469-480.

20. Kovats, S., Main, E. K., Librach, C., Stubblebine, M., Fisher, S. J., AND DeMars, R. (1990). A class I antigen, HLA-G, expressed in human trophoblasts. Science 248: 220233.

21. LAWlor, D. A., Zemmour, J., ENNIS, P. D., AND PARHAM, P. (1990). Evolution of class-I MHC genes and proteins: From natural selection to thymic selection. Annu. Rev. Immunol. 8: 23-63.

22. Lawrance, S. K., Das, H., Pan, J., And Weissman, S. M. (1985). The genomic organization and nucleotide sequence of the HLA-SB(DP) alpha gene. Nucleic Acids Res. 13: 75157527.

23. Lawrance, S. K., Smith, C. L., Srivastava, R., Cantor, C. R., AND WEISSMAN, S. M. (1987). Megabase-scale mapping of the HLA gene complex by pulsed field gel electrophoresis. Science 235: 1387-1390.

24. Levine, F., Erlich, H., Mach, B., Leach, R., White, R., AND PIOUs, D. (1985). Deletion mapping of HLA and chromosome 6p genes. Proc. Natl. Acad. Sci. USA 82: 3741-3745.

25. Little, R. D., Porta, G., Carle, G. F., Schlesinger, D., AND D'Urso, M. (1989). Yeast artificial chromosomes with 200- to 800-kilobase inserts of human DNA containing HLA, $\mathrm{V}_{\mathrm{s}}$, 5S, and Xq24-Xq28 sequences. Proc. Natl. Acad. Sci. USA 86: 1598-1602.

26. ORR, H. T., AND DeMars, R. (1983). Class I-like HLA genes map telomeric to the HLA-A2 locus in human cells. Nature 302: 534-536.

27. OTT, J. (1985). “Analysis of Human Genetic Linkage,” Johns Hopkins Univ. Press., Baltimore, MD.

28. Parham, P., Lawlor, D. A., Lomen, C. E., and Ennis, P. D. (1989). Diversity and diversification of $H L A-A, B, C$ alleles. J. Immunol. 142: 3937-3950.

29. PoustKa, A., and Lehrach, H. (1986). Jumping libraries and linking libraries: The next generation of molecular tools in mammalian genetics. Trends Genet. 2: 174-179.

30. Ragoussis, J., van der Bliek, A., Trowsdale, J., and ZIEGLER, A. (1986). Mapping of HLA genes using pulsed-field gradient electrophoresis. FEBS Lett. 204: 1-4.

31. Ragoussis, J., Bloemer, K., Pohla, H., Messer, G., Weiss, E., AND ZIEGLeR, A. (1989). A physical map including a new class I gene (cda12) of the major histocompatibility complex (A2/B13 haplotype) derived from a monosomy 6 mutant cell line. Genomics 4: 301-308.

32. Kinke de WIT, T. F., Vloemans, S., Van Den Elsen, P. J., HAWORTH, A., AND STERN, P. L. (1990). Differential expression of the HLA class I multigene family by human embryonal carcinoma and choriocarcinoma cell lines. $J$. Im munol. 144: 1080-1087.

33. Rommens, J. M., Iannuzzi, M. C., Kerem, B.-S., Drumm, M. L., Melmer, G., Dean, M., Rozmahel, R., Cole, J. L. Kennedy, D., Hidaka, N., Zsiga, M., Buchwald, M., RioRDAN, J. R., Tsui, L.-C., AND Collins, F. S. (1989). Identification of the cystic fibrosis gene: Chromosome walking and jumping. Science 245: 1059-1065.

34. Shukla, H., Swaroop, A., SRIVAstava, R., AND Weissman, 
S. M. (1990). The mRNA of a human class I gene HLA G/ HLA 6.0 exhibits a restricted pattern of expression. Nucleic Acids Res. 18: 2189.

35. Sood, A. K., Pereira, D., AND Weissman, S. M. (1981). Isolation of cDNA clone from human histocompatibility antigen HLA-B7 by use of an oligodeoxynucleotide primer. Proc. Natl. Acad. Sci. USA 78: 616-620.

36. Southern, E. M. (1975). Detection of specific sequences among DNA fragments separated by gel electrophoresis. $J$. Mol. Biol. 98: 503-517.

37. Srivastava, R., Duceman, B. W., Biro, P. A., Sood, A. S., AND Weissman, S. M. (1985). Molecular organization of the class I gene of human major histocompatibility complex. Immunol. Rev. 84: 93-121.

38. Srivastava, R., Lawrance, S. K., Smith, C. L., Cantor, C. R., AND WEISSMAN, S. M. (1986). Long-range and molecular mapping of the human major histocompatibility complex. Trans. Assoc. Am. Physicians 99: 1-12.

39. Srivastava, R., Chorney, M. J., Lawrance, S. K., Pan, J., SMITH, Z., SMITH, C. L., AND WeISSMaN, S. M. (1987). Structure, expression, and molecular mapping of a divergent member of the class I $H L A$ gene family. Proc. Natl. Acad. Sci. USA 84: 4224-4228.

40. SRIVAStava, R., AND Lambert, M. E. (1989). Structure, expression and function of class I genes of the human major histocompatibility complex. In "Immunology: Clinical, Fundamental and Therapeutic Aspects" (B. P. Ram, M. C. Harris, and P. Tyle, Eds.), Vol. 1, pp. 99-136, VCH Publishers, New York.

41. Steinmetz, M., Stephan, D., AND Fischer Lindahl, K. (1986). Gene organization and recombinational hotspots in the murine major histocompatibility complex. Cell 44: 895904.

42. STroynowski, I. (1990). Molecules related to class-I major histocompatibility complex antigens. Annu. Rev. Immunol. 8: $501-530$

43. van Seventer, G. A., Spits, H., Yssel, H., Melief, C. J. M., AND IVANYI, P. (1988). Differential recognition by human cytoxic $\mathrm{T}$ cell clones of human M1 fibroblasts transfected with an HLA-B7 gene (JY150) suggests the existence of two different HLA-B7 alleles in the cell line JY (HLA-A2-B7.7Cw-Dr4,w6). J. Immunol. 141: 417-422.

44. WeIss, E. (1987). Molecular biology of the mouse $Q$ region. Immunol. Res. 6: 179-191.

45. Weissman, S. M. (1987). Molecular genetic techniques for mapping the human genome. Mol. Biol. Med. 4: 133-143.

46. Zemmour, J., Koller, B. H., Ennis, P., Geraghty, D. E., LAWlor, D. A., ORR, H. T., AND Parham, P. (1990). HLA$A R$, an inactivated antigen-presenting locus related to HLAA. J. Immunol. 144: 3619-3629. 